\title{
ADHESION OF SALMONELLA ENTERITIDIS TO STAINLESS STEEL SURFACES
}

\author{
Kelly Oliveira ${ }^{1}$; Tereza Oliveira ${ }^{2}$; Pilar Teixeira ${ }^{3}$; Joana Azeredo ${ }^{3}$; Rosário Oliveira ${ }^{3 *}$ \\ ${ }^{1}$ Centro Universitário de Maringá, Maringá, PR, Brasil; ²Universidade Estadual de Londrina, Centro de Ciências Agrárias, \\ Departamento de Tecnologia de Alimentos e Medicamentos, Londrina, PR, Brasil; ${ }^{3}$ Centro de Engenharia Biológica, \\ Universidade do Minho, Campus de Gualtar, Braga, Portugal
}

Submitted: November 30, 2006; Returned to authors for corrections: February 08, 2007; Approved: March $23,2007$.

\begin{abstract}
Adhesion of microorganisms to food processing surfaces and the problems it causes are a matter of strong concern to the food industry. Contaminated food processing surfaces may act as potential sources of transmission of pathogens in food industry, catering and in the domestic environments. Several studies have shown that adhesion of bacteria to surfaces partly depends upon the nature of the inert surfaces and partly upon the bacterial surface properties. The aim of this study was to compare the adhesion of four different strains of Salmonella Enteritidis to stainless steel 304 (SS 304). The effect of surface hydrophobicity and surface elemental composition on the adhesion process was also analysed. Hydrophobicity was evaluated through contact angle measurements using the sessile drop method. All the strains studied showed positive values of the degree of hydrophobicity $\left(\Delta G_{l w l}\right)$ and so can be considered hydrophilic while stainless steel revealed a hydrophobic character. Bacterial cell surface composition was measured using X-ray photoelectron spectroscopy (XPS). The XPS results corroborated the similarity of the values of the degree of hydrophobicity obtained by contact angles. The different Salmonella strains showed similar elemental composition and cell surface physico-chemical properties. Nevertheless, $S$. Enteritidis MUSC presented higher adhesion ability to SS $304(\mathrm{p}<0.05)$. It can be concluded that the physico-chemical properties of the strain does not explain the ability of adhesion to stainless steel. Other factors like the production of polysaccharides must be considered.
\end{abstract}

Key words: Adhesion, Salmonella Enteritidis, hydrophobicity

\section{INTRODUCTION}

Adhesion of microorganisms to food processing equipment surfaces is of great concern to the food industry. Adhered microorganisms to solid surfaces can have the potential to act as a chronic source of microbial contamination, which may compromise food quality and represent a significant health hazard (2). Several studies showed that cross-contamination can result from hands, sponges/clothes and utensils either in domestic kitchens or in any food processing plant $(13,16,22,23)$. For instance, Salmonella spp. is able to colonize different inert food contact surfaces to form biofilms $(3,14,18,21)$. So, it has been recognized that a greater understanding of the interaction between microorganisms and food-processing surfaces is required to control these problems.

Salmonellosis has been one of the most commonly reported food-borne illnesses worldwide. In many countries, including Brazil, Salmonella Enteritidis is the most frequently isolated serotype. Epidemiological evidence has linked the majority of outbreaks in State of Paraná, Brazil, to contaminated poultry products.

Stainless steel has been the material of choice for working surfaces and kitchen sinks for many years due to its mechanical strength, corrosion resistance, longevity and ease of fabrication (17). In the food processing industry most of the surfaces are of stainless steel including, pipelines and tanks (1), machinery

*Corresponding Author. Mailing address: Centro de Engenharia Biológica - Universidade do Minho, Campus de Gualtar - 4710 - 057 Braga, Portugal. Tel.: 351253604409 ou 351 253678986. E-mail: roliveira@ deb.uminho.pt 
and working surfaces $(18,26,28)$. Moreover, it is relatively resistant to chemical attack by oxidizing and other sanitizing agents used in the food industry, like hypochlorite, peracetic acid and iodophors (5).

The mechanisms governing the adhesion of Salmonella spp. to inert surfaces are not completely understood; several studies have shown that adhesion of bacteria partly depends upon the nature of the inert surfaces and partly upon the bacterial surface properties $(7,9,19)$. Hydrophobicity and surface charge are the most important surface properties in the adhesion process as demonstrated by innumerous studies $(18,25,27,32,36)$.

The understanding of microbial adhesion is of major importance in preventing undesirable biofilm formation. Therefore, the aim of this study was to compare the ability of adhesion of four strains of Salmonella Enteritidis to stainless steel 304 (SS 304), in order to investigate the behavior of different strains of the same species. The effect of surface hydrophobicity and surface elemental composition in the adhesion process was also analysed.

\section{MATERIALSAND METHODS}

\section{Media and growth conditions}

The strains used in this study are presented in Table1.

All bacterial isolates were maintained in trypticase soy agar (TSA). Every strain was subcultured twice in trypticase soy broth (TSB) at $37^{\circ} \mathrm{C}$ in an orbital shaker $(130 \mathrm{rpm})$, overnight. The cells were then harvested by centrifugation at $5000 \mathrm{~g}$ for 10 min and washed three times with phosphate buffered saline (PBS 0.1M pH 7). The pellets were resuspended in PBS to an inoculum level of $10^{8} \mathrm{CFU} / \mathrm{ml}$, determined by optical density.

\section{Material used as substratum}

The test surface was stainless steel (304, finish $\left.n^{\circ} 4\right)$, commonly present in the food industry and used in domestic kitchens. The coupons were cut in $0.8 \times 0.8 \mathrm{~cm}^{2}$, washed in a

Table 1. Bacterial isolates used in this study.

\begin{tabular}{|c|c|}
\hline Strains & Source \\
\hline Salmonella Enteritidis EMB ${ }^{1}$ & $\begin{array}{l}\text { Water from poultry } \\
\text { packaging }\end{array}$ \\
\hline Salmonella Enteritidis MUSC ${ }^{1}$ & Breast meat of poultry \\
\hline Salmonella Enteritidis $\mathrm{AL}^{2}$ & $\begin{array}{l}\text { Food sample related to } \\
\text { food-borne outbreak }\end{array}$ \\
\hline Salmonella Enteritidis $\mathrm{PC}^{2}$ & Fecal human sample \\
\hline
\end{tabular}

The bacterial isolates were obtained from:

${ }^{1}$ Food Microbiology Lab., Depart. of Food and Dry Technology, University of Londrina, Pr, Brazil; ${ }^{2}$ LACEN (Central Paraná Public Health Laboratory Service). solution of a commercial detergent (Sonasol Pril, Henkel Ibérica S.A., Portugal) in ultrapure water for $30 \mathrm{~min}$ and then thoroughly rinsed in ultrapure water (to remove any remaining detergent), followed by immersion in ethanol $90 \%$ for $30 \mathrm{~min}$ to completely degrease the surface and in sterile water.

\section{Hydrophobicity and surface free energy}

Hydrophobicity was evaluated through contact angle measurements and using the approach of van Oss and coworkers (37-39). In this approach, the degree of hydrophobicity of a given material (1) is expressed as the free energy of interaction between two entities of that material when immersed in water (w) $-\Delta G_{l w l}$. If the interaction between the two entities is stronger than the interaction of each entity with water $\left(\Delta G_{l w l}<\right.$ 0 ) the material is considered hydrophobic. Conversely, if $\Delta G_{l w l}$ $>0$ the material is hydrophilic. $\Delta G_{l w l}$ can be calculated through the surface tension components of the interacting entities, according to:

$$
\begin{aligned}
& \Delta G_{I w l}=-2\left(\sqrt{\gamma_{l}^{L W}}-\sqrt{\gamma_{w}^{L W}}\right)^{2}+4 \\
& \left(\sqrt{\gamma_{I}^{+} \gamma_{w}^{-}}+\sqrt{\gamma_{I}^{-} \gamma_{w}^{+}}-\sqrt{\gamma_{l}^{+} \gamma_{l}^{-}}-\sqrt{\gamma_{w}^{+} \gamma_{w}^{-}}\right)
\end{aligned}
$$

where $\gamma^{\mathrm{LW}}$ accounts for the Lifshitz-van der Waals component of the surface free energy and $\gamma^{+}$and $\gamma$ are the electron acceptor and electron donor parameters, respectively, of the Lewis acidbase component $\left(\gamma^{\mathrm{AB}}\right)$, with $\gamma^{\mathrm{AB}}=2 \sqrt{\gamma^{+} \gamma^{-}}$.

The surface tension components of a solid material are obtained by measuring the contact angles of three pure liquids (one apolar and two polar), with well known surface tension components, followed by the simultaneous resolution of three equations of the form:

$$
(1+\cos \theta) \gamma_{1}^{\text {TOT }}=2\left(\sqrt{\gamma_{\mathrm{s}}^{\mathrm{LW}} \gamma_{1}^{\mathrm{LW}}}+\sqrt{\gamma_{\mathrm{s}}^{+} \gamma_{1}^{-}}+\sqrt{\gamma_{\mathrm{s}}^{-} \gamma_{1}^{+}}\right)
$$

where $\theta$ is the contact angle and $\gamma^{\mathrm{TOT}}=\gamma^{\mathrm{LW}}+\gamma^{\mathrm{AB}}$.

Contact angle measurements (at least 25 determinations with each liquid on stainless steel and on each microbial strain) were performed automatically with the aid of an image analysis system (G2/G40) installed in a standard contact angle apparatus (Kruss$\mathrm{GmbH}$ ). The images were transmitted by a video camera to a personal computer for evaluation. All the measurements were performed at room temperature. In the case of bacterial cells, the measurements were performed on a cell lawn using the sessile drop method described by Busscher et al. (6). Briefly, bacteria were deposited on a $0.45 \mu \mathrm{m}$ cellulose acetate membrane filter by filtration of the suspension using negative pressure. To standardize the moisture content, the filters were then transferred onto Petri dishes containing $1 \%(w / v)$ agar with 
$10 \%$ (v/v) glycerol. Measurements of advancing water contact angles were carried out at $25^{\circ} \mathrm{C}$ and three liquids with different polarities were used, water $(\mathrm{W})$, formamide $(\mathrm{F})$ and $\alpha$ bromonaphtalene $(\alpha-\mathrm{B})$. Their surface tension components were obtained from literature (20).

Hydrophobicity of the stainless steel was estimated by the same technique, with direct measurements of contact angles on stainless steel surface, after degreasing and cleaning.

\section{X-ray photoelectron spectroscopy}

Bacterial cell surface composition was measured using Xray photoelectron spectroscopy (XPS). The bacterial cells were grown in $200 \mathrm{ml} \mathrm{TSB}$ at $37^{\circ} \mathrm{C}$ under $120 \mathrm{rpm}$ for $18 \mathrm{~h}$ and washed three times in deionized water by centrifugation (10 min at 5000 $\mathrm{g}$ and $\left.4^{\circ} \mathrm{C}\right)$. A volume of $200 \mathrm{ml}$ of a cellular suspension $\left(10^{9}\right.$ cells/ $\mathrm{ml}$ ) was vacuum filtered through an acetate cellulose membrane of $45 \mu \mathrm{m}$. The membrane, completely covered with cells, was immediately frozen with liquid nitrogen and then stored at $-80^{\circ} \mathrm{C}$ until the subsequent step of lyophilization. Freeze drying was performed at $10 \mathrm{~Pa}$, overnight. The samples were placed in a dessicator, at room temperature and immediately analyzed by XPS. The XPS analysis was performed using an apparatus ESCALAB 200A, with a VG5250 software and data analysis. The spectrometer used monochromatized $\mathrm{Mg} \mathrm{K} \alpha \mathrm{X}$-ray radiation $(15.000 \mathrm{eV})$. The constant pass energy of the analyzer was $20 \mathrm{eV}$ and it was calibrated with reference to $\mathrm{Ag} 3 \mathrm{~d}_{5 / 2}(368.27$ $\mathrm{eV})$. The pressure during analysis was under $1 \times 10^{-6} \mathrm{~Pa}$. The spectra were recorded following the sequence $\mathrm{C} 1 \mathrm{~s}, \mathrm{O} 1 \mathrm{~s}, \mathrm{~N} 1 \mathrm{~s}$, $\mathrm{P} 2 \mathrm{p}$. The elemental composition was defined as the ratio between oxygen and carbon $(\mathrm{O} / \mathrm{C})$, nitrogen and carbon $(\mathrm{N} / \mathrm{C})$ or phosphorous and carbon $(\mathrm{P} / \mathrm{C})$.

\section{Adhesion assays}

The coupons of stainless steel were immersed in $2 \mathrm{ml}$ of each bacterial suspension containing $10^{8} \mathrm{CFU} / \mathrm{ml}$. After $1 \mathrm{~h}$ at $25^{\circ} \mathrm{C}$ with constant shaking at $100 \mathrm{rpm}$, the coupons were rinsed twice with PBS to remove poorly adhered bacteria. An aliquot of $20 \mu \mathrm{l} / \mathrm{ml}$ of a 4',6-diamidino-2-phenylindole (DAPI) solution was added to each coupon containing the plates and incubated for $30 \mathrm{~min}$ in the dark. After this time, the coupons were rinsed with sterile distilled water and the adherent microorganisms were quantified by automatic enumeration using epifluorescence microscopy. Thirty fields per coupon were scanned and the fluorescent cells were enumerated. Computerized image analysis software (Image-Pro Plus, Media Cybernetics) was used for the quantitative estimation of the adherent cells. All experiments were done in triplicate.

\section{Statistical analysis}

The resulting data were analysed using SPSS software (Statistical Package for the Social Sciences). One-way ANOVA with Bonferroni test was used to compare the number of adhered cells. All tests were performed with a confidence level of $95 \%$.

\section{RESULTS AND DISCUSSION}

The contact angles formed by the three liquids (water, formamide, and $\alpha$-bromonaphtalene) on stainless steel and on bacterial lawns are present in Table 2.

The values of water contact angles for all Salmonella strains tested were quite similar $\left(9.7^{\circ}-14.0^{\circ}\right)$ and were somewhat lower then those reported in the literature $\left(17^{\circ}-35^{\circ}\right)(10,30)$. The different serovars of Salmonella studied and the non-uniformity on bacterial surface may explain the results obtained in this study (11). The water contact angle value gives preliminary information about the degree of hydrophobicity of cells. The sample is considered hydrophobic or hydrophilic if the angle is higher or lower than $65^{\circ}$, respectively (40). According to this criterion, all Salmonella strains are hydrophilic whereas stainless steel is hydrophobic.

The values of the contact angles of the three liquids were used to calculate cell surface tension parameters and the degree of hydrophobicity (Table 3).

Table 2. Values of contact angles (in degrees) measured with water $\left(\theta_{\mathrm{W}}\right)$, formamide $\left(\theta_{\mathrm{f}}\right)$ and $\alpha$-bromonaphatelene $\left(\theta_{\alpha-\mathrm{B}}\right)$ on stainless steel and on the different Salmonella assayed.

\begin{tabular}{lccc}
\hline & \multicolumn{3}{c}{ Contact angle $\left({ }^{\circ}\right)( \pm$ SD $)$} \\
\cline { 2 - 4 } & $\theta_{\mathrm{W}}$ & $\theta_{\mathrm{f}}$ & $\theta_{\alpha-\mathrm{B}}$ \\
\hline Stainless steel & $81.2( \pm 0.9)$ & $60.0( \pm 1.1)$ & $23.4( \pm 0.5)$ \\
$S$. Enteritidis EMB & $10.8( \pm 2.2)$ & $15.6( \pm 1.8)$ & $26.1( \pm 4.2)$ \\
$S$. Enteritidis MUSC & $13.5( \pm 1.6)$ & $15.9( \pm 2.3)$ & $27.6( \pm 1.7)$ \\
$S$. Enteritidis PC & $14.0( \pm 4.4)$ & $17.0( \pm 3.2)$ & $31.7( \pm 2.8)$ \\
$S$. Enteritidis AL & $9.7( \pm 1.9)$ & $14.8( \pm 2.6)$ & $27.2( \pm 2.5)$ \\
\hline
\end{tabular}

SD - standard deviation.

Table 3. Values of the components of surface tension $\left(\gamma^{\mathrm{LW}}, \gamma^{+}\right.$, $\left.\gamma^{-}\right)$and degree of hydrophobicity $\left(\Delta G_{l w l}\right)$ of stainless steel and bacterial cells.

\begin{tabular}{lcccc}
\hline & \multicolumn{4}{c}{ Surface tension $\left(\mathbf{m} \mathbf{J} / \mathbf{m}^{2}\right)$} \\
\cline { 2 - 5 } & $\gamma^{\mathrm{LW}}$ & $\gamma^{+}$ & $\gamma^{-}$ & $\Delta G_{l w l}$ \\
\hline Stainless steel & 40.81 & 0.00 & 5.84 & -59.80 \\
\hline$S$. Enteritidis EMB & 39.89 & 0.97 & 55.99 & 34.12 \\
$S$. Enteritidis MUSC & 39.49 & 1.07 & 54.41 & 32.15 \\
$S$. Enteritidis PC & 38.06 & 1.22 & 54.48 & 32.28 \\
$S$. Enteritidis AL & 39.50 & 1.05 & 55.84 & 33.79 \\
\hline
\end{tabular}


The $\Delta G_{l w l}$ values obtained were very similar for all the strains tested being all strains hydrophilic $\left(\Delta G_{l w l}>0\right)$. From Table 3, it can be observed that all cell surfaces were predominantly electron donors (higher values of $\gamma$ ), with low electron acceptor parameters $\left(\gamma^{+}\right)$.

Considering the values of water contact angle $\left(81.2^{\circ}\right)$ and $\Delta G_{l w l}=-59.8 \mathrm{~mJ} / \mathrm{m}^{2}$, the stainless steel assayed was hydrophobic, which is in accordance with several authors $(12,30,33)$. A point to be noted is that stainless steel does not have an electron acceptor parameter but is only electron-donor $(\gamma)$.

The chemical composition of microbial cells surface obtained by XPS spectra is usually expressed in terms of N/C, O/C and P/ $\mathrm{C}$ ratios (35). The corresponding values for the microorganisms assayed are presented in Table 4. All strains used in this study exhibited high $\mathrm{O} / \mathrm{C}$ values, ranging from 0.465 to 0.584 , and low $\mathrm{P} / \mathrm{C}$ values, ranging from 0.008 to 0.0137 .

Microbial surface thermodynamics is a reflection of the physico-chemistry of bacterial surfaces, which is controlled by macromolecular components, e.g., lipo-polysaccharides, proteins and exopolymers, varying in quantity with growth conditions and from strain to strain. The amount of the macromolecular components can be represented by a variety of different functional groups $(31,34)$. In previous works, cell surface hydrophobicity, assessed by water contact angle, was directly correlated with the concentration of nitrogen or carbon involved in hydrocarbon form and inversely correlated with the oxygen concentration $(4,11,29)$. In this study, the water contact angle was directly correlated with the N/C ratio whereas hydrophobicity expressed as $\Delta G_{l w l}$, was inversely correlated with the oxygen concentration. The XPS results corroborated the similarity of the hydrophobicity values. Cerca et al. (8) correlated the N/C ratio of $S$. epidermidis strains with cell surface hydrophobicity, with the less hydrophobic cells exhibiting the lower N/C ratio. The presence of proteinic appendages is often reflected in a high nitrogen concentration at the cell surface (29).

The number of cells of different strains of Salmonella Enteritidis adhered to stainless steel are presented in Fig. 1. The extent of adhesion of Salmonella MUSC was statistically different $(\mathrm{p}<0.05)$ of the other strains.

Liu et al. (24) predicted that when both bacterial and support surfaces are hydrophobic, microbial adhesion is highly facilitated.

Table 4. Ratios of the major chemical elements of bacterial surface composition of the Salmonella strains obtained by XPS analysis.

\begin{tabular}{lccc}
\hline \multicolumn{1}{c}{ Strain } & N/C & O/C & P/C \\
\hline$S$. Enteritidis EMB & 0.066 & 0.584 & 0.008 \\
S. Enteritidis MUSC & 0.118 & 0.465 & 0.009 \\
S. Enteritidis PC & 0.118 & 0.466 & 0.009 \\
$S$. Enteritidis AL & 0.114 & 0.479 & 0.008 \\
\hline
\end{tabular}

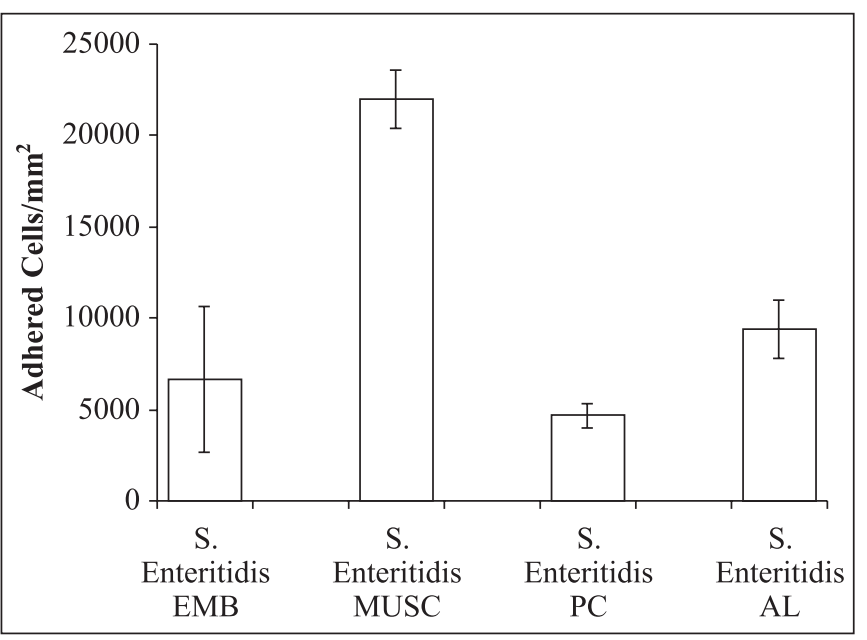

Figure 1. Number of adhered cells to stainless steel 304.

If both bacterial and support surfaces are hydrophilic, microbial adhesion would proceed with difficulty. Thus, an increase in cell surface hydrophobicity would favor cell adhesion on both hydrophilic and hydrophobic supports surface. Also, Assanta et al. (1) suggested that Arcobacter butzzeri could attach in higher numbers to surfaces with low surface free energy and Aeromonas hydrophila cells had a tendency to attach in high numbers to hydrophobic surfaces. However, in the present case, the extent of adhesion does not seem to be directly related with cell surface hydrophobicity, because the strains show similar values of $\Delta G_{l w l}$ (Table 3). A recent study by Henriques et al. (15), reported the increase in the number of adhered yeast cells to acrylic by an increase in the interactions between the electrondonor groups of acrylic and the electron-acceptor groups of cells. Once more this can not be the rationale to explain the different extents of adhesion displayed by the Salmonella strains assayed.

\section{CONCLUSIONS}

The different extent of adhesion of four Salmonella Enteritidis strains to stainless steel 304 could not be explained in terms of cell surface physico-chemical properties. Other factors might be governing the process of adhesion, namely the production of exopolysaccharides is worth to be investigated.

This study proves that adhesion is strongly strain dependent and in this sense the adhesion ability of Salmonella serovars can be considered a factor of virulence.

\section{ACKNOWLEDGEMENTS}

Kelly Oliveira fully acknowledges CAPES/ Brazil for the grant BEX 0891/01-0. 


\section{RESUMO}

\section{Adesão de Salmonella enteritidis a superfícies de aço inoxidável}

A adesão de microrganismos a superfícies de processamento de alimentos e os problemas que daí resultam são matéria de grande preocupação para a indústria alimentar. Superfícies de processamento de alimentos contaminadas podem actuar como uma potencial fonte de transmissão de patogénicos na indústria alimentar, restauração e em ambientes domésticos. Diversos estudos têm demonstrado que a adesão de bactérias a superfícies depende, por um lado, da natureza das superfícies inertes e, por outro, das propriedades superficiais das bactérias. $\mathrm{O}$ objectivo deste trabalho consistiu na comparação da capacidade de adesão de 4 cepas diferentes de Salmonella Enteritidis ao aço inoxidável 304 (SS 304). Analisou-se também o efeito da hidrofobicidade e da composição elementar no processo de adesão. A hidrofobicidade foi determinada através da medição de ângulos de contacto usando o método da gota séssil. Todas as cepas apresentaram valores positivos do grau de hidrofobicidade $\left(\Delta G_{l w l}\right)$ podendo, assim, ser consideradas hidrofílicas enquanto o aço inoxidável revelou um carácter hidrofóbico. A composição elementar da superfície das células bacterianas foi medida através de espectroscopia de fotoelectrões X (XPS). Os resultados do XPS corroboraram a similaridade de valores do grau de hidrofobicidade obtidos por ângulos de contacto. As diferentes cepas de Salmonella apresentaram uma composição elementar e propriedades físicoquímicas semelhantes. No entanto, a Salmonella MUSC apresentou uma capacidade de adesão ao aço inoxidável mais elevada $(\mathrm{p}<0.05)$. Pode então concluir-se que as propriedades físico-químicas das cepas não explicam a capacidade de adesão ao aço inoxidável, devendo ser considerados outros factores tais como a produção de exopolissacáridos.

Palavras-chave: Adesão, Salmonella Enteritidis, hidrofobicidade

\section{REFERENCES}

1. Assanta, M.A.; Roy, D.; Lemay, M.J.; Montpetit, D. (2002). Attachment of Arcobacter butzleri, a new waterborne pathogen, to water distribution pipe surfaces. J. Food Prot., 65, 1240-1247.

2. Barners, L.M.; Lo, M.F.; Adams, M.R.; Chamberlain, A.H.L. (1999). Effect of milk proteins on adhesion of bacteria to stainless steel surfaces. Appl. Environ. Microbiol., 65, 4543-4548.

3. Bonafonte, M.A; Solano, C.; Sesma, B.; Alvarez, M.; Montuega, L.; Garcia-Ros, D.; Gamazo, C. (2000). The relationship between glycogen synthesis, biofilm formation and virulence in Salmonella enteritidis. FEMS Microbiol. Let., 191, 31-36.

4. Boonaert, C.J.P.; Rouxhet, P.G. (2000). Surface of lactic acid bacteria: Relationships between chemical composition and physicochemical properties. Appl. Environ. Microbiol., 66, 2548-2554.

5. Boulange-Peterson, L. (1996). Process of bioadhesion on stainless steel surfaces and cleanability: a review with special reference to the food industry. Biofouling, 10, 275-300.
6. Busscher, H.J.; Weerkamp, A.H.; van der Mei, H.C.; van Pelt, A.W.J.; de Jong, H.P.; Arends, J. (1984). Measurements of the surface free energy of bacterial cell surfaces and its relevance for adhesion. Appl. Environ. Microbiol., 48, 980-983.

7. Carballo, J.; Ferreiros, C.M.; Criado, M.T. (1992). Factor analysis in the evaluation of the relationship between bacterial adherence to biomaterials and changes in free energy. J. Biomater. Appl., 7, 130141.

8. Cerca, N.; Pier, G.B.; Vilanova, M.; Oliveira, R.; Azeredo, J. (2005). Quantitative analysis of adhesion and biofilm formation on hydrophilic and hydrophobic surfaces of clinical isolates of Staphylococcus epidermidis. Research Microbiol., 156, 506-514.

9. Chamberlain, A.H.L.; Johal, S. (1988). Biofilms on meat processing surfaces. In: Houghton, D.R., Smith, R.N., Eggins, H.O.W. (eds.) Biodeterioration 7. Elsevier Applied Science, London, p.57-61.

10. Dickson, J.S.; Koohmaraie, (1989). M. Cell surface charge characteristics and their relationship to bacterial attachment to meat surfaces. Appl. Env. Microbiol., 55, 832-836.

11. Donlon, B.; Colleran, E.A. (1993). Comparison of different methods to determine the hydrophobicity of acetogenic bacteria. J. Microbiol. Methods, 17, 27-37.

12. Flint, S.H.; Brooks, J.D.; Bremer, P.J. (2000). Properties of stainless steel substrate, influencing the adhesion of thermo-resistant streptococci. J. Food Eng., 43, 235-242.

13. Gorman, R.; Bloomfield, S.; Adley C.C. (2002). A study of crosscontamination of food-borne pathogens in the domestic kitchen in the Republic of Ireland. Int. J. Food Microbiol., 76, 143-150.

14. Gough, N.L.; Dodd, C.E.R. (1998). The survival and disinfection of Salmonella typhimurium on chopping board surfaces of wood and plastic. Food Control, 9, 363-368.

15. Henriques, M.; Azeredo, J.; Oliveira, R. (2004). Adhesion of Candida albicans and Candida dubliniensis to acrylic and hydroxyapatite. Colloids Surf. B: Biointerfaces, 33, 235-241.

16. Hilton, A.C.; Austin, E. (2000). The kitchen dishcloth as a source of and vehicle for foodborne pathogens in a domestic setting. Int. J. Environ. Res., 10, 257-261.

17. Holah, J.T.; Thorpe, R.H. (1990). Cleanability in relation to bacterial retention on unused and abraded domestic sink materials. J. App. Microbiol., 69, 599-608.

18. Hood, S.K.; Zottola, E.A. (1997). Adherence to stainless steel by foodborne microorganisms during growth in model food systems. Int. J. Food Microbiol., 37, 145-153.

19. Hood, S.K.; Zottola, E.A. (1995). Biofilms in food processing. Food Contr., 6, 9-18.

20. Janczuk, B.; Chibowski, E.; Bruque, J.M.; Kerkeb, M.L.; GonzalezCaballero, F.J. (1993). On the consistency of surface free energy components as calculated from contact angle of different liquids: an application to the cholesterol surface. J. Colloid Interface Sci., 159, 421-428.

21. Joseph, B.; Otta, S.K.; Karunasagar, I. (2001). Biofilm formation by Salmonella spp. on food contact surfaces and their sensitivity to sanitizers. Int. J. Food Microbiol., 64, 367-372.

22. Kusumaningrum, H.D.; Riboldi G.; Hazeleger, W.C.; Beumer, R.R. (2003). Survival of foodborne pathogens on stainless steel surfaces and cross-contamination to foods. Int. J. Food Microbiol., 85, 227-236.

23. Kusumaningrum, H.D.; van Putten, M.M.; Rombouts, F.M.; Beumer, R.R. (2002). Effects of antibacterial dishwashing liquid on foodborne pathogens and competitive microorganisms in kitchen sponges. $J$. Food Prot., 65, 61-65.

24. Liu, Y.; Yang, S.F.; Li, Y.; Xu, H.; Qin, L.; Tay, J.H. (2004). The influence of cell and substratum surface hydrophobicities on microbial attachament. J. Biotech., 110, 251-256.

25. Millsap, K.W.; Reid, G.; van der Mei, H.C.; Busscher, H.J. (1996). Adhesion of Lactobacillus species in urine and phosphate buffer to silicone rubber and glass under flow. Biomaterials, 18, 87-91. 
26. Parker, S.G.; Flint, S.H.; Palmer, J.S.; Brooks, J.D. (2001). Factors influencing attachment of thermophilic bacilli to stainless steel. $J$. App. Microbiol., 90, 901-908.

27. Pereira, M.A.; Alves, M.M.; Azeredo, J.; Mota, M.; Oliveira, R. (2000). Influence of physico-chemical properties of porous microcarriers on the adhesion of an anaerobic consortium. J. Ind Microbiol. Biotechnol., 24, 181-186.

28. Rossoni, E.M.M.; Gaylarde C.C. (2000). Comparison of sodium hypochlorite and peracetic acid as sanitizing agents for stainless steel food processing surfaces using epifluorescence microscopy. Int. J. Food Microbiol., 61, 81-85.

29. Rouxhet, P.G.; Mozes, N.; Dengis, P.B.; Dufrêne, Y.F.; Gerin, P.A.; Genet, M.J. (1994). Application of X-ray photoelectron spectroscopy to microorganisms. Colloids Surf. B: Biointerfaces, 2, 347-369.

30. Sinde, E.; Carballo, J. (2000). Attachment of Salmonella spp. and Listeria monocytogenes to stainless steel, rubber and polytetrafluorethylene: the influence of free energy and the effect of commercial sanitizers. Food Microbiol., 17, 439-447.

31. Strevett, K.A.; Chen, G. (2003). Microbial surface thermodynamics and applications. Res. Microbiol., 154, 329-335.

32. Teixeira, P.; Oliveira, R. (1999). Influence of surface characteristics on the adhesion of Alcaligenes denitrificans to polymeric substrates. J. Adhesion Sci. Technol., 13, 1287-1294.
33. Teixeira, P.; Lopes, Z.; Azeredo, J.; Oliveira, R.; Vieira, M.J. (2005) Physico-chemical surface characterization of a bacterial population isolated from a milking machine. Food Microbiol., 22, 247-251.

34. Vadillo-Rodríguez, V.; Busscher, H.J.; Norde, W.; de Vries, J.; van der Mei, H. (2004). Atomic force microscopic corroboration of bond aging for adhesion of Streptococcus thermophilus to solid substrata. J. Colloid Interface Sci., 278, 251-254.

35. van der Mei, H.; de Vries, J.; Busscher, H.J. (2000). X-ray photoelectron spectroscopy for the study of microbial cell surfaces. Surface Science Rep., 39, 1-24.

36. van Loosdrecht, M.C.M.; Lyklema J.; Norde W.; Schraa G.; Zehnder, A.J.B. (1987). The role of bacterial cell wall hidrophobicity in adhesion. Appl. Environ. Microbiol., 53, 1893-1897.

37. van Oss, C.J.; Chaudhury, M.K.; Good, R.J. (1987). Monopolar surfaces. Adv. Colloid Interface Sci., 28, 35-64.

38. van Oss, C.J.; Ju, L.; Chaudhury, M.K.; Good, R.J. (1989). Estimation of the polar parameters of the surface tension of liquids by contact angle measurements on gels. J. Colloid Interface Sci., 128, 313-319.

39. van Oss, C.J.; Good, R.J.; Chaudhury, M.K. (1988). Additive and nonadditive surface tension components and the interpretation of contact angles. Langmuir, 4, 884-891.

40. Vogler, E.A. (1998). Structure and reactivity of water at biomaterial surfaces. Adv. Colloid Interface Sci., 74, 69-117. 